\title{
ANTIBIOTIC CONSUMPTION IN THE LATVIAN TEACHING HOSPITAL 2000-2008
}

\author{
Elīna Dimiṇa ${ }^{\star, \star \star}$, Mārtiņš Akermanis ${ }^{\star \star \star}$, and Uga Dumpis ${ }^{\star, \star *}$ \\ * Pauls Stradinš̌ Clinical University Hospital, Pilsoṇu iela 13, Rĩga, LV-1002, LATVIA; \\ e-mail: uga.dumpis@stradini.Iv \\ ${ }^{* *}$ Faculty of Medicine, University of Latvia, Šarlotes iela 1a, Rīga, LATVIA \\ *** Rīga Stradiṇš University, Dzirciema iela 16, Rīga, LV-1007, LATVIA \\ Communicated by Andrejs Ërglis
}

\begin{abstract}
Antibiotics are one of the most commonly used drugs in hospital care and significantly contribute to healthcare costs. Recently, there has been significant interest raised on the environmental impact of antibiotic use, in particular on how it effects resistance selection pressure. Rapid global spread of multiresistant bacteria requires improved understanding on how changes in antibiotic use affect resistance selection. We present a unique study on antibiotic consumption and its trends over an eight-year period. Data were obtained from the pharmaceutical database system. The study period extended from January 2000 through December 2008. Antibiotic use was expressed as a rate - defined daily doses (DDD) per 100 patient days (DDD/100) in a quarter year. The total amount of antibiotics used for systemic treatment at the beginning of the period (first quarter of 2000) was 38.7 DDD per 100 bed days and increased to 72.6 DDD per 100 bed days $(r=0.81)$ by the $4^{\text {th }}$ quarter of 2008. Despite variability during the study period, a significant trend was observed with an average increase of 0.97 (95\% Cl: 1.2; 3.2) per quarter. Penicillin was the most common antibiotic group used at the hospital in the study period and demonstrated the greatest increase in consumption $(r=0.92)$. The consumption rates of fluoroquinolones were high and also showed a significant increase $(r=0.76)$. We observed a significant increase of antibiotic consumption in our hospital during the study period, which lacked a clear explanation. This increase was mostly due to increased use of amoxicillinum/enzyme inhibitor and ceftriaxone. Analysis of consumption should be continued to assess the impact of educational interventions.
\end{abstract}

Key words: antibiotic consumption, defined daily doses (DDD).

\section{INTRODUCTION}

Use of antibiotics is an essential part of hospital care. There is a growing recognition of the environmental impact of antibiotic treatment and overuse of expensive broad spectrum antibiotics on the hospital micro flora. Overuse increases the indirect costs of antimicrobial therapy. Therefore, it is important to look at antibiotic consumption trends in relation with antimicrobial resistance patterns in a hospital. Knowledge of antibiotic consumption trends will enable measures to be adopted governing future use. Thus, it could be possible to avoid unnecessary healthcare costs and preventing possible environmental effects (Ruiz Bremon et al., 2000; Brown et al., 2005; Seaton et al., 2007; VlahovicPalcevski et al., 2007)

The aim of the present study was to investigate antimicrobial use trends and patterns in the Pauls Stradin̨š Clinical University Hospital.

\section{MATERIALS AND METHODS}

Pauls Stradiņ̌̌ Clinical University Hospital is a tertiary level hospital with approximately 1,000 beds. Speciality services include several highly specialised departments (cardio surgery, cardiology, neurosurgery, transplantology) and severe patients from across the country receive treatment in this hospital.

Data were obtained from the pharmaceutical database. The study period extended from January 2000 through December 2008. Year quarter antibiotic rates of consumption were calculated.

The data entered took into account the number of packages of each brand and conversion was made to the number of units of active drug ingredient. Active drug ingredients were classified according to the World Health Organization (WHO)/Anatomical Therapeutic Chemical (ATC) classification (http://www.whocc.no). Subsequently, the amount of drug in grams was transferred into the technical units DDD (defined daily doses), recommended by WHO as a common method for describing the use of drugs. DDD is the assumed average maintenance dose per day for a drug used for its main indication in adults and is defined by experts. It is a technical unit, therefore, not used or recommended as the prescribed dose because antibiotic dosage discrepancies exist between countries and hospitals. Antibi- 
otic use was expressed as the rate DDD per 100 patient days (DDD/100) in a year quarter (Ruiz Bremon et al., 2000; Curtis et al., 2004; Hutchinson et al., 2004; Muller et al., 2006; Goryachkina et al., 2008).

\section{RESULTS}

The total amount of antibiotics used for systemic treatment at the beginning of the period (first quarter 2000) was 38.7 DDD per 100 bed days, which by the $4^{\text {th }}$ quarter of 2008 had increased to 72.6 DDD per 100 bed days $(r=0.81)$. Despite variability during the study period, a significant trend was observed with an average increase 0.97 (95\% CI: -1.2 ; 3.2) during a quarter (Fig. 1).

Some seasonal variability was observed during the entire study period. The highest consumption occurred yearly in the $4^{\text {th }}$ quarter at the start of winter and decreased in the $1^{\text {st }}$ quarter of the next year. We compared antibiotic consumption for $4^{\text {th }}$ quarter in all study years and observed an even more significant yearly increase $(r=0.89)$.

The antibiotic use trends for the major antibiotic groups are shown in Figure 2. The results indicate that the three most common antibiotic groups used at the hospital in the study period were penicillins, cephalosporins and fluoroquinolones. Penicillins demonstrated the greatest increase in consumption, with an average increase of $0.59 \mathrm{DDD} / 100$ bed days in a quarter $(\mathrm{r}=0.92, P<0.01)$. The consumption rates of fluoroquinolones $(\mathrm{r}=0.76, P<0.01)$ and macrolides $(\mathrm{r}=0.74, P<0.05)$ also showed significant increases. Ciprofloxacin was the most commonly used fluoroquinolone, and clarithromycin was the most popular macrolide. The cephalosporin group and aminoglycosides showed a significant decline in use $(\mathrm{r}=-0.86$ and $\mathrm{r}=-0.81$, $P<0.01)$.
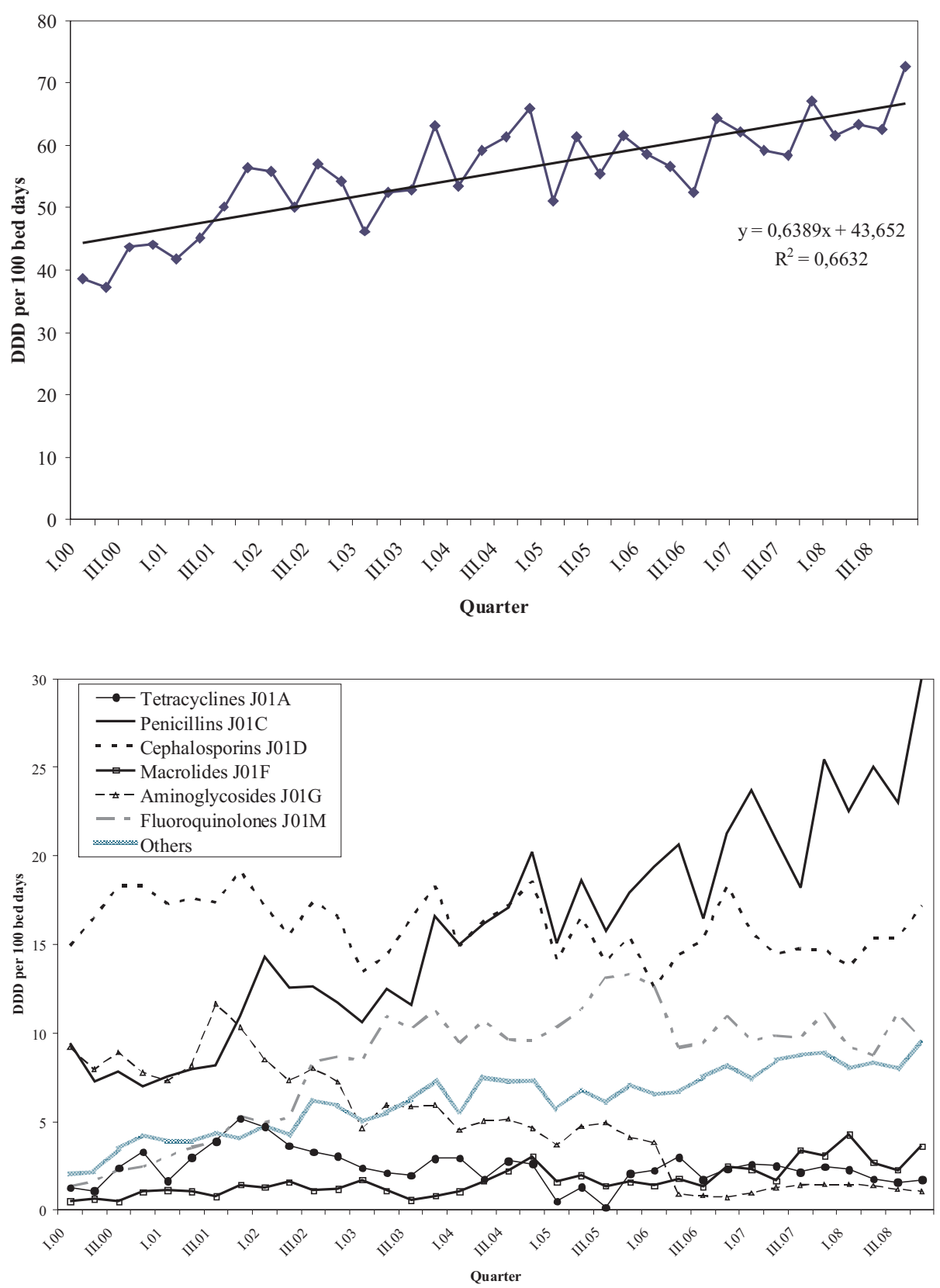

Fig. 1. Total use of antibacterial drugs for systemic use in Pauls Stradiņ̌̌ Clinical University Hospital 2000-2008, DDD/100 bed day.

Fig. 2. Consumption of different groups of antibiotics, 2000-2008, DDD/100 bed days. 
The mostly used antibiotic subgroups were broad spectrum penicillins (J01CA), first, second and third generation cephalosporins, penicillin combinations (J01CR) and also fluoroquinolones (J01MA). Before 2006, cephazolin was the most frequently prescribed antibiotic, but later it was apparently replaced by amoxicillinum/enzyme inhibitor (J01CR) and ciprofloxacin (J01MA). Increased use of penicillin could be explained by use of amoxicillinum/enzyme inhibitor since consumption of broad spectrum penicillins (J01CA) decreased during the last two study years. (Fig. 3)

Use of first-generation cephalosporins declined rapidly with subsequent increase of second and third generation cephalosporins. Carbapenem use remained rather low over the study period (Fig. 4).

\section{DISCUSSION}

Total antibiotic consumption calculated in DDD per bed days nearly doubled during the study period. This was an unexpected finding, as we expected increased awareness of antimicrobial resistance and the danger of unnecessary antibiotic use, especially since several education activities and regular feedback from point prevalence studies performed each year in the hospital.

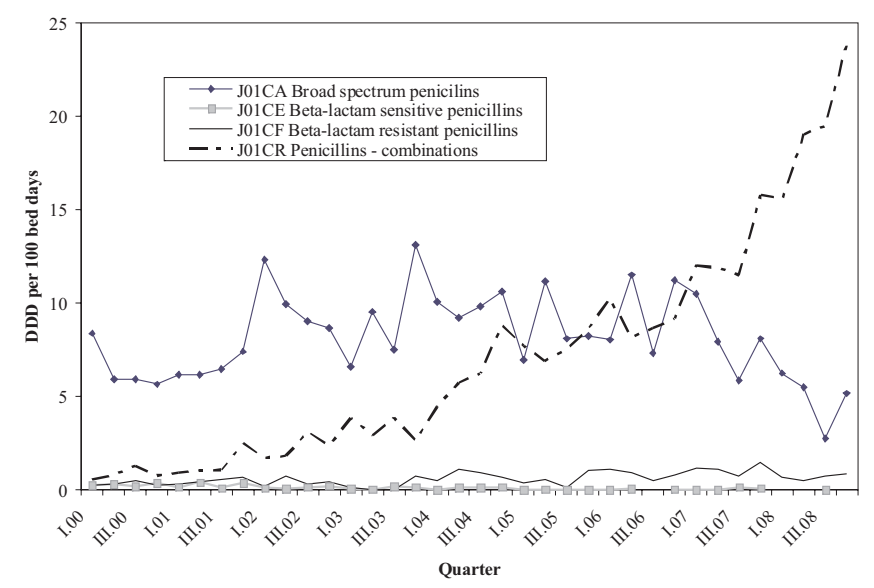

Fig. 3. Trends for penicillin consumption (2000-2008)

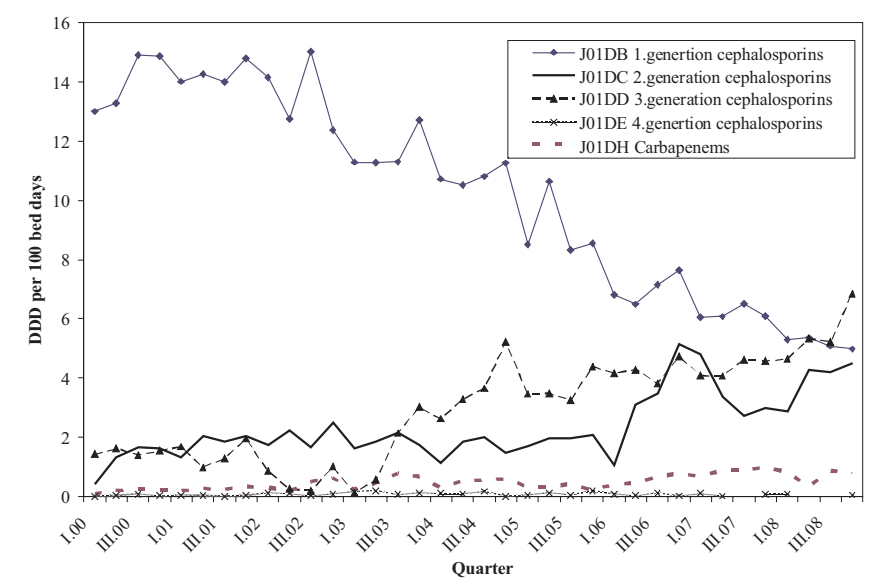

Fig. 4. Trends for cephalosporin and carbapenem consumption (2000-2008)
A possible explanation for this increase could be a gradual increase in a number of very sick patients hospitalised late during the disease course, due to decreased access to healthcare facilities. Shorter hospital stay and introduction of more invasive procedures could also contribute to increased antibiotic use. Nevertheless, these reasons cannot explain the high increase of such significance (Curtis et al., 2004)

Length of treatment cannot be examined by using the DDD approach. Extended courses of antibiotics can significantly increase consumption. Regular point prevalence studies did not show significant increase in the prevalence of patients receiving antibiotics. Also, more frequent choice of combination treatments could lead to increased consumption. (Curtis et al., 2004; Hutchinson et al., 2004; Muller et al., 2006; Vlahovic-Palcevski et al., 2007).

There are huge variations in the total exposure to antibiotics in hospital care in Europe. Higher consumption than in our hospital was observed in southern countries, but similar and lower in Northern countries (Anonymous, 2004; Vander Stichele et al., 2006; Willemsen et al., 2006)

An important consideration for increased antibiotic use could be an increase in the incidence of nosocomial infection and spread of multiresistant nosocomial pathogens. During the study period, emergence of new nosocomial pathogens like MRSA, VRE, and ESBL producing Gr negatives was recorded, but regular point prevalence studies annually performed in the hospital did not indicate an overall increase of prevalence of nosocomial infections (unpublished data) (Miklasevics et al., 2004).

Use of DDDs might cause some study bias due to difference between doses of antibiotics used in our hospital and the DDD used in calculation. For example, the usual dosing of ceftriaxone in our hospital is $2 \mathrm{~g}$ per day, but DDD used in the calculation is $1 \mathrm{~g}$. Nevertheless, this bias cannot explain the large increase of use (Hutchinson et al., 2004; Muller et al., 2006; Vander Stichele et al., 2006; Goryachkina et al., 2008).

Over the last five years, use of penicillins was promoted due to rapid spread of MRSA in Latvian hospitals and emerging evidence that cephalosporins and fluoroquinolones were implicated in particularly high resistance selection pressure. Therefore, increased use of penicillins was expected. Apparently, this intervention resulted in increased use of coamoxiclav (J01CR) and unnecessary decrease in the use of broad spectrum penicillins (J01CA). This requires correction, since broad spectrum penicillins still remain the choice for respiratory infections and there is no need to replace them with co-amoxiclav (Vander Stichele et al., 2006)

We recorded a consistent increase of antibiotic consumption in the $4^{\text {th }}$ quarter of the year with a subsequent decrease in the $1^{\text {st }}$ quarter of the following year. There is no clear explanation for this, since acute respiratory infection remains an important cause of hospitalisation also in January and February. Perhaps this reduction can be explained by the lack of financial quota for scheduled hospitalisation (operations, investigation) at the end of the year, and therefore, a larger proportion of emergency hospitalisations. 
In conclusion, we observed major changes of antibiotic prescription pattern during the eight-year study period. Increase of consumption and the significant changes in the choice of different antibiotic groups were the main findings of our study. Further studies are needed to benchmark the antibiotic use to design future strategies, to curb the spread of multiresistant nosocomial pathogens.

\section{ACKNOWLEDGMENTS}

The work was supported by the National Research Programme in Medicine 2006-2009, project No. 12, "Elaboration of approaches for modern diagnostics, epidemiology, prevention and therapy of the most clinically important multidrug resistant bacteria".

\section{REFERENCES}

Anonymous (2005). A Report on Swedish Antibiotic Utilisation and Resistance in Human Medicine, 2004. Swedish Institute for Infectious Disease Control. Swedres.

Brown, E.M., Nathwani, D. (2005). Antibiotic cycling or rotation: A systematic review of the evidence of efficacy. J. Antimicrob. Chemother., 55, 6-9.

Curtis, C., Marriott, J., Langley, C. (2004). Development of prescribing indicator for objective quantification of antibiotic usage in secondary care. $J$. Antimicrob. Chemother., 54, 529-533.

Goryachkina, K., Babak, S., Burbello, A., Wettermark, B., Bergman, U. (2008). Quality use of medicines: A new method of combining antibiotic consumption and sensitivity data-applicatin in Russian hospital. Pharmacoepidemiol. Drug Saf., 17, 636-644.
Hutchinson, J.M., Patric, D.M., Marra, F., Ng, H., Bowie, W.R., Heule, L., Muscat, M., Monnet, D.L. (2004). Measurement of antibiotic consumption: A practical guide to the use of the Anatomical Therapeutic Chemical classification and Defined Daily Dose system methodology in Canada. Can. J. Infect. Dis., 15, 29-35.

Miklasevics, E., Haeffman, S., Balode, A., Sanchez, B., Martinsons, A., Olsson-Liljequist, B., Dumpis, U. (2004). Report on the first PVL-positive community acquired MRSA strain in Latvia. Euro Surveill., 9(11), 29-30.

Muller, A., Monnet, D.L., Talon, D., Henon, T., Bertrand, X. (2006). Discrepancies between prescribed daily doses and WHO defined daily doses of antimicrobials at a university hospital. Brit. J. Clin. Pharmacol., 61, 585-591.

Ruiz Bremon, A., Ruiz-Tovar, M., Perez Gorricho, B., Diaz de Torres, P., Lopez Rodriguez, R. (2000). Non-hospital consumption of antibiotics in Spain: 1987-1997. J. Antimicrob. Chemother., 45, 395-400.

Seaton, R.A., Nathwani, D., Burton, P., McLaughlin, C., Mac Kenzie, A.R., Dundas, S., Ziglam, H., Gourlay, Y., Beard, K., Douglas, E. (2007). Point prevalence survey of antibiotic use in Scottish hospitals utilising the Glasgow Antimicrobial Audit Tool (GAAT). Int. J. Antimicrob. Agents, 29, 693-699.

Vander Stichele, R.H., Elseviers, M.M., Ferech, M., Blot, S., Goossens, H. (2006). Hospital consumption of antibiotics in 15 European countries: Results of the ESAC Retrospective Data Collection (1997-2002). J. Antimicrob. Chemother., 58, 159-167.

Vlahovic-Palcevski, V., Dumpis, U., Mitt, P., Gulbinovic, J., Struwe, J., Palcevski, G., Stimac, D., Lagergren, A., Bergman, U. (2007). Benchmarking antimicrobial drug use at university hospitals in five European countries. Clin. Microbiol. Infect., 13, 277-283.

Willemsen, I., Groenhuijzen, A., Bogaers, D., van Stuurman, A., van Keulen, P., Kluytmans, J.(2007). Appropriateness of antimicrobial therapy measured by repeated prevalence surveys. Antimicrob. Agents Chemother., 51, 864-867.

Received 11 July 2009

\section{ANTIBIOTIKU PATĒRIN̦Š PAULA STRADIN̦A KLĪNISKAJĀ UNIVERSITĀTES SLIMNĪCĀ NO 2000 LĪDZ 2008. GADAM}

Laika periodā no 2000. gada līdz 2008. gadam tika apkopoti Paula Stradiṇa Klīniskās universitātes slimnīcas antibiotiku patēriṇa dati. Tika apkopota visa aptiekas informācija un antibiotiku patēriņš pārrēķināts saskaņā ar starptautiski pieņemtu metodolog̣iju definētajās dienas devās (DDD) uz 100 pacientu gultu dienām. Pētītajā laika periodā antibiotiku patēriṇš uz 100 pacientu gultu dienām ir gandrīz divkāršojies no 38,7 uz 72,6 DDD uz 100 pacientu gultu dienām. Visvairāk tika lietotas penicilīna grupas antibiotikas, kuru patēriņš arī pieauga galvenokārt uz amoksicilīna/enzīmu inhibitora rēkina. Līdzīgi pieauga ar fluorhinolonu grupas un ceftriaksona patēriņš. Šì pieauguma iemesli nav pilnībā noskaidroti. Patērina pieaugums noteikti palielina mikroorganismu rezistences selekcijas spiedienu. Būtu nepieciešams analizēt mikroorganismu rezistences dinamiku slimnīcā šajā laikā, diemžēl šāda informācija pilnībā nav pieejama. 